\title{
Ефективність місцевого застосування антимікробних засобів з програмованим вивільненням антисептика в рани пацієнтів з опіковою травмою
}

\author{
В. І. Нагайчук, Г. К. Палій, О. А. Назарчук, І. М. Вовк, Д. В. Дмитрієв
}

Вінницький національний медичний університет імені М. І. Пирогова

\section{Efficacy of local application of antimicrobal preparations with the programmed access of antiseptic from the wound in patients with the burn trauma}

\author{
V. I. Nahaychuk, H. K. Paliy, O. A. Nazarchuk, I. M. Vovk, D. V. Dmytriiev \\ Vinnytsya National Medical University named after M. I. Pyrogov
}

\begin{abstract}
Реферат
Мета. Вивчити динаміку вмісту клітинних елементів та ступінь мікробної колонізації (МК) опікових ран у гострому періоді опікової хвороби при застосуванні антимікробної композиції (АМК) з програмованим вивільненням декаметоксину (ДКМ).

Матеріали і методи. Досліджували цитологічно (метод ранових відбитків), мікробіологічно (кількісна, якісна ідентифікація мікроорганізмів - МO) загоєння опікових ран III ступеня $(3,7,14,21$-ша доба). У групі спостереження (n=32) застосовували засоби з програмованим пролонгованим вивільненням ДКМ; у групі порівняння (n=29) - повідон-йод. Результати. A. baumannii, P. aeruginosa найчастіше колонізували опікові рани. При застосуванні АМК встановлено зменшення МК ран (14-та доба - $\log 5,5$ КУО/мл; 21-ша доба - $\log 2,4$ КУО/мл), раннє (3, 7-ма доба) збільшення вмісту фагоцитуючих клітин ( $<0,001)$, маркерів регенерації $(\mathrm{p}<0,05)$ та зменшення запального компонента 3 14-ї доби. У групі порівняння визначали дегенеративний фагоцитоз на 7-му добу і пролонгацію запального компонента $321-ш о і ̈ ~$ доби.

Висновки. Застосування АМК з програмованим вивільненням ДКМ ефективно зменшує МК, сприяє прискоренню репарації ран.

Ключові слова: антимікробні засоби; антисептики; опіки; рани; загоєння ран.

Abstract

Objective. To study dynamics of the cellular elements content and degree of microbial colonization (MC) of the burn wounds in acute period of the burn disease while application of antimicrobial composition (AMC) with programmed release of decametoxine

Materials and methods. Healing of the burn wounds of Degree III (3, 7, 14, 21-st day) was investigated cytologically (method of the wound imprints), microbiologically (quantitative, qualitative identification of microorganisms - MO). In the observation Group $(\mathrm{n}=32)$ the measures with programmed prolonged release of decametoxine were applied, and in the comparison Group ( $\mathrm{n}=29)$ - povidone-iodine.

Results. A.baumannii, P. aeruginosa have colonized the burn wounds most frequently. Reduction of the wounds MC (14-th day - log 5.5 CFU (colony-forming unit) $/ \mathrm{ml} ; 21$-st day - $\log 2.4 \mathrm{CFU} / \mathrm{ml}$ ), early $(3,7$-th day) increase of the phagocytic cells $(\mathrm{p}<0.001)$, the marker's regeneration $(\mathrm{p}<0.05)$, and reduction of inflammatory component from 14-th day were established while application of the AMC. In the comparison Group a degenerative phagocytosis was determined on the 7-th day and prolongation of inflammatory component - on the 21-st day.

Conclusion. AMC application with programmed release of decametoxine reduces MC effectively, promotes acceleration of the wounds reparation.

Keywords: antimicrobial preparations; antiseptics; burns; wounds; healing of wounds.
\end{abstract}

Лікування хворих з тяжкими опіками залишається актуальною і складною проблемою сучасної медицини та потребує постійного вдосконалення, незважаючи на новітні досягнення комбустіології. Значно перешкоджають ефективному лікуванню опіків інфекційні ускладнення [1]. Тривале перебування в стаціонарах інтенсивної терапії збільшуе ризик розвитку внутрішньогоспітальної інфекції в 5 - 10 разів [2]. Особливо небезпечними є інфекційні ускладнення, спричинені поліантибіотикорезистентними збудниками Р. aeruginosa (29\%),
Acinetobacter spp. (9\%), Klebsiella spp. (8\%), Enterobacter spp. (7\%), Proteus spp. (6\%) $[3,4]$.

У комплексному лікуванні хворих з тяжкими опіками важливу роль відводять місцевому застосуванню ефективних протимікробних лікарських засобів, спрямованих на пригнічення збудників у рані та їх ерадикацію 3 ранових поверхонь, які є потенційними вхідними воротами і резервуаром опікової інфекції. Персистенція умовнопатогенних МО в рані на фоні зниженої імунної реактивності хворого сприяє поглибленню некрозу, 
гальмує регенераторні процеси, відтерміновує хірургічну пластику, погіршує прогноз [5].

Серед багатьох напрямків боротьби 3 антибіотикорезистентними МО пріоритетним залишається застосування засобів з потужними мікробоцидними властивостями, широким спектром протимікробної дії, які тривало забезпечують оптимальний антимікробний режим безпосередньо в рані. Розширення уявлень щодо цитоморфологічних змін у ділянці опіку за умов пролонгованої програмовано-дозованої доставки в рану ефективних антисептиків має суттєвий науковий та практичний інтерес у плані лікування опіків шляхом знищення збудників у рані.

Мета дослідження: вивчити динаміку вмісту клітинних елементів та ступінь МК опікових ран у гострому періоді опікової хвороби при застосуванні АМК з ДКМ.

\section{Матеріали і методи дослідження}

Викладено аналіз результатів цитологічного та мікробіологічного спостереження за перебігом загоєння ран у 61 хворого з опіками III ступеня (площа ураження від 10 до 60\% поверхні тіла), які перебували на лікуванні у Вінницькій обласній клінічній лікарні ім. М.І. Пирогова в 2016 - 2017 рр. Всім пацієнтам проводили хірургічне лікування (ранню некректомію в перші три доби, ксенодермопластику), комплексне загальне (збалансовану інфузійно-трансфузійну, антибактеріальну, симптоматичну терапію) і місцеве лікування в необхідному обсязі відповідно до протоколів лікування таких хворих.

Пацієнтів поділено на дві групи: групу спостереження $(n=32)$ і групу порівняння $(n=29)$. Вік пацієнтів групи спостереження - $(43,8 \pm 6,12)$ року, групи порівняння - $(41,8 \pm 8,7)$ року. Хворим групи спостереження під час перев'язок рани обробляли декасаном (реєстраційне посвідчення № UA/5364/01/01 від 22.12.2016 р., наказ № 1391 МО3 України), ранову поверхню закривали відповідно до методики (Пат. України № 93662) марлевою пов'язкою, імпрегнованою АМК, що містила антисептичний лікарський препарат ДКМ (реєстраційне посвідчення № UA/12180/01/01 від 29.03.2017 р., наказ № 341 МО3 України), масова частка якого дорівнювала 0,1\%, та карбоксиметилкрохмаль, оксиетилцелюлозу, полівінілацетат (Пат. України № 74853). Хворим групи порівняння ранові поверхні обробляли повідон-йодом (бетадином), на рани накладали волого-висихаючі пов'язки з цим же антисептиком. В обох групах пов'язки змінювали в залежності від показань щоденно або через добу.

Мікробіологічні та цитологічні дослідження ранового вмісту, одержаного з поверхні опікових ран, проводили в умовах бактеріологічної лабораторії кафедри мікробіології, вірусології та імунології Університету. 3 метою оцінки динаміки перебігу загоєння опікової рани при різних способах місцевого лікування матеріал для цитоскопічного та мікробіологічного дослідження забирали на 3, 7, 14, 21-шу добу від моменту отримання опікової травми. Ексудат для цитологічного дослідження забирали шляхом ранових відбитків з поверхні рани за методикою М. П. Покровської. Паралельно стерильним тампоном забирали матеріал для бактеріологічного дослідження з метою кількісного визначення МК рани та встановлення збудника ранової інфекції.
Забарвлені за Романовським-Гімзою препарати досліджували цитологічно за допомогою імерсійної мікроскопії (зб. ×900), клітини підраховували не менше ніж у 10 полях зору, визначали середню кількість лейкоцитів, моноцитів/макрофагів, полібластів, фібробластів, у тому числі профібробластів, тучних клітин, лімфоцитів та інших клітин з метою встановлення фази перебігу ранового процесу.

Для порівняння відносного вмісту певних клітин у рановому ексудаті вираховували, який відсоток становить їх кількість від загальної кількості клітин, виявлених мікроскопічно.

Мікробіологічне дослідження проводили шляхом секторального посіву на щільні поживні середовища для визначення мікробного забруднення рани, видову ідентифікацію виділених МО здійснювали за морфологічними, культуральними, біохімічними критеріями. Кількісне визначення загальної МК рани визначали за стандартною методикою.

\section{Результати}

Цитологічним дослідженням матеріалу 3 поверхні ран пацієнтів з площею ураження до 20\% у фазі альтерації (3-тя доба після отримання термічної травми) встановлено переважання поліморфно-ядерних лейкоцитів у групі спостереження і групі порівняння - відповідно $(74,2 \pm 2,4) \%$ та $(68,9 \pm 5,8) \%$ від усіх клітин у полі зору. У групі спостереження вміст моноцитів/макрофагів був у 2,3 разу вищий, ніж у групі порівняння ( $<<0,001)$. Серед інших клітин судинного походження (еритроцитів, гранулоцитів, лімфоцитів) значною була кількість еритроцитів в обох групах: спостереження - $(6,4 \pm 1,7) \%$, порівняння - $(23,3 \pm 6,6) \%$. При збільшенні площі опіку від 21 до 50\% відносний вміст фагоцитуючих клітин у цитограмах пацієнтів зменшувався, натомість збільшувався вміст еритроцитів, що можна пояснити зменшенням місцевої опірності макроорганізму внаслідок тяжкої опікової травми (див. маблицю).

На 3-тю добу термічної травми у пацієнтів групи спостереження $з$ площею ураження 21 - 30\% вміст лейкоцитів у ранових мазках-відбитках у 1,9 разу перевищував відповідний показник пацієнтів групи порівняння (p $<0,01)$. Відносний вміст фагоцитів при площі ураження 31 - 50\% в обох групах не мав істотних відмінностей, однак у групі спостереження вміст моноцитів був вищий у 3,7 разу - $(6,7 \pm 0,5) \%(\mathrm{p}<0,001)$. Вміст моноцитів у цитограмах пацієнтів групи спостереження був на 2 - 8\% вищим, ніж у пацієнтів групи порівняння. При площі опікової рани більше 50\% у препаратах виявляли велику кількість залишків некротичних тканин, вміст еритроцитів у пацієнтів групи порівняння сягав 70\%; у пацієнтів групи спостереження кількість еритроцитів була меншою на 21,2\%, а вміст фагоцитуючих клітин (лейкоцитів, моноцитів) у 2 рази перевищував відповідний показник у групі порівняння і сягав $48 \%$.

В обох групах у препаратах виявляли МО в невеликій кількості. Проте тільки при площі ураження до 20\% поверхні тіла було визначено ознаки фагоцитозу мікробних колонізатів. Серед інших клітин, які реєстрували поодиноко на декілька полів зору, були базофіли, еозинофіли, лімфоцити. Полібластів, фібробластів не виявляли. 


\begin{tabular}{|c|c|c|c|c|c|c|c|}
\hline \multicolumn{8}{|c|}{ Характеристика цитограм ранової поверхні у хворих з опіками III ступеня у різні терміни спостереження } \\
\hline \multirow{5}{*}{$\begin{array}{c}\text { Термін } \\
\text { спостереження, } \\
\text { доба }\end{array}$} & \multirow{5}{*}{ Клітини } & \multicolumn{6}{|c|}{ Вміст клітин у рановому ексудаті, \% } \\
\hline & & \multicolumn{6}{|c|}{ Площа ураження, \% } \\
\hline & & \multicolumn{2}{|c|}{$21-30$} & \multicolumn{2}{|c|}{$31-50$} & \multicolumn{2}{|c|}{ більше 50} \\
\hline & & \multicolumn{2}{|c|}{ групи } & \multicolumn{2}{|c|}{ групи } & \multicolumn{2}{|c|}{ групи } \\
\hline & & спостереження & порівняння & спостереження & порівняння & спостереження & порівняння \\
\hline \multirow{4}{*}{ 3-тя } & Лейкоцити & $60,1 \pm 6,1$ & $31,6 \pm 2,1$ & $47,2 \pm 5,6$ & $43,4 \pm 6,8$ & $41,7 \pm 1,2$ & $22,9 \pm 8,2$ \\
\hline & Макрофаги & $6,7 \pm 0,5$ & $1,8 \pm 0,8$ & $6,4 \pm 0,9$ & $4,1 \pm 1,0$ & $7,7 \pm 1,3$ & $5,1 \pm 4,8$ \\
\hline & Еритроцити & $31,4 \pm 6,7$ & $65,8 \pm 3,2$ & $45,0 \pm 6,4$ & $52,1 \pm 8,0$ & $48,8 \pm 9,6$ & $70 \pm 13,5$ \\
\hline & Інші & $1,8 \pm 0,3$ & $0,8 \pm 0,2$ & $1,4 \pm 0,6$ & $0,4 \pm 0,1$ & $1,8 \pm 0,6$ & $2,0 \pm 1,5$ \\
\hline \multirow{5}{*}{ 7-ма } & Лейкоцити & $65,5 \pm 2,1$ & $63,6 \pm 7,2$ & $64,8 \pm 4,1$ & $72,6 \pm 1,7$ & $62,5 \pm 8,2$ & $57,4 \pm 5,6$ \\
\hline & Макрофаги & $13,2 \pm 0,8$ & $6,7 \pm 1,7$ & $12,4 \pm 1,6$ & $9,6 \pm 0,6$ & $11,1 \pm 2,1$ & $9,2 \pm 3,1$ \\
\hline & Полібласти & $11,0 \pm 0,9$ & $2,2 \pm 1,3$ & $3,7 \pm 0,7$ & $3,2 \pm 1,2$ & $3,3 \pm 1,1$ & $3,6 \pm 1,6$ \\
\hline & Фібробласти & $3,3 \pm 0,5$ & $0,4 \pm 0,3$ & $0,3 \pm 0,2$ & - & - & - \\
\hline & Інші & $6,9 \pm 1,1$ & $27,1 \pm 2,9$ & $18,8 \pm 1,7$ & $14,6 \pm 0,8$ & $23,1 \pm 3,8$ & $29,8 \pm 4,1$ \\
\hline \multirow{5}{*}{ 14-та } & Лейкоцити & $51,8 \pm 3,2$ & $67,5 \pm 4,9$ & $54,3 \pm 5,6$ & $79,2 \pm 1,3$ & $57,3 \pm 7,6$ & $65,1 \pm 7,3$ \\
\hline & Макрофаги & $12,4 \pm 1,1$ & $10,7 \pm 1,3$ & $14,7 \pm 1,6$ & $11,5 \pm 0,5$ & $12,7 \pm 1,4$ & $7,3 \pm 1,0$ \\
\hline & Полібласти & $19,1 \pm 2,6$ & $5,0 \pm 1,8$ & $9,7 \pm 1,4$ & $5,6 \pm 1,2$ & $9,6 \pm 2,7$ & $8,5 \pm 2,6$ \\
\hline & Фібробласти & $6,6 \pm 1,4$ & $1,4 \pm 0,5$ & $2,5 \pm 0,8$ & $1,0 \pm 0,6$ & $2,6 \pm 1,6$ & $1,1 \pm 0,8$ \\
\hline & Інші & $10,1 \pm 0,9$ & $15,4 \pm 1,2$ & $18,5 \pm 2,1$ & $2,7 \pm 0,9$ & $17,8 \pm 3,4$ & $18,0 \pm 3,3$ \\
\hline \multirow{5}{*}{ 21-ша } & Лейкоцити & $35,2 \pm 3,1$ & $69,5 \pm 6,5$ & $51,1 \pm 4,3$ & $76,9 \pm 3,2$ & $61,1 \pm 6,5$ & $76,0 \pm 3,2$ \\
\hline & Макрофаги & $15,3 \pm 0,8$ & $15,3 \pm 2,2$ & $17,7 \pm 1,9$ & $12,9 \pm 0,9$ & $16,1 \pm 1,7$ & $13,1 \pm 2,7$ \\
\hline & Полібласти & $25,8 \pm 1,8$ & $8,9 \pm 3,5$ & $12,1 \pm 1,4$ & $5,7 \pm 1,3$ & $12,1 \pm 2,4$ & $7,6 \pm 1,1$ \\
\hline & Фібробласти & $14,7 \pm 2,7$ & $2,9 \pm 1,6$ & $5,2 \pm 1,1$ & $2,0 \pm 1,2$ & $3,8 \pm 2,2$ & $0,1 \pm 0,09$ \\
\hline & Інші & $8,9 \pm 1,0$ & $3,4 \pm 1,4$ & $13,9 \pm 2,9$ & $2,5 \pm 0,7$ & $6,9 \pm 2,6$ & $3,2 \pm 1,8$ \\
\hline
\end{tabular}

Враховуючи велику кількість лейкоцитів, наявність тканинного детриту та невелику кількість МО, цитограми у пацієнтів з площею ураження до 20\% та у пацієнтів 3 площею ураження 21 - 30\% групи спостереження віднесено до III (дегенеративно-запального) типу за Штейнбергом, а цитограми у пацієнтів 3 площею опікової рани більше 30\% та у пацієнтів 3 площею ураження 21 - 30\% групи порівняння - до II (дегенеративно-некротичного) типу.

На 7-му добу спостереження за даними цитологічного дослідження визначали ознаки запальної фази перебігу ранового процесу, про що свідчило збільшення вмісту фагоцитуючих клітин, за винятком цитограм пацієнтів групи спостереження 3 площею ураження до 20\%. Порівняно з 3-тьою добою спостереження відмічали зменшення відносного вмісту лейкоцитів - (56,7 \pm $2,4) \%$ за рахунок зростання кількості макрофагів - $(18,4$ $\pm 0,9) \%$, появи полібластів - $(11,3 \pm 1,3) \%$, профібробластів - $(5,4 \pm 0,9) \%$. Результати свідчили про розвиток репаративних процесів ранових поверхонь, зменшення запального компонента в перебігу ранового процесу.

При інших площах ураження відносний вміст лейкоцитів на поверхні ран зростав, зменшувалась кількість еритроцитів, некротичних залишків. Водночас цитологічно встановлено зростання вмісту макрофагів, появу інших клітин тканинного походження, а саме полібластів, а у пацієнтів з площею ураження до 50\% - поодиноких профібробластів.

При опіках площею 21 - 30\% вміст лейкоцитів у препаратах не перевищував $(65,5 \pm 2,1) \%$ - у групі спостереження та $(63,6 \pm 7,2) \%$ - у групі порівняння. Аналіз вмісту маркерів регенераторних процесів (макрофагів, поліб- ластів, профібробластів) показав, що вміст макрофагів у пацієнтів групи спостереження у 2 рази вищий, ніж у пацієнтів групи порівняння, - $(6,7 \pm 1,7) \%(p<0,05)$. У пацієнтів групи спостереження на поверхні ран переважали полібласти - $(11,0 \pm 0,9) \%$, що було у 5 разів більше, ніж у пацієнтів групи порівняння ( $<<0,001)$.

Серед інших клітин реєстрували еритроцити, лімфоцити, поодинокі тучні клітини. Позитивну динаміку перебігу ранового процесу та початок репарації ранової поверхні встановлено при площі ураження 31 - 50\% за зростанням кількості макрофагів у 2 рази в порівнянні 3 3-тьою добою у групі спостереження - $(12,4 \pm 1,6) \%$ i групі порівняння - (9,6 \pm 0,6)\% та появою поодиноких гістіоцитів.

У пацієнтів з площею ураження більше 50\% за даними цитограм ран визначали фазу запалення, про що свідчили високі показники вмісту поліморфно-ядерних лейкоцитів в обох групах, які достовірно не відрізнялись: група спостереження - $(62,5 \pm 8,2) \%$, група порівняння $(57,4 \pm 5,6) \%(\mathrm{p}>0,05)$. Повільно зростав вміст макрофагів та з'являлися поодинокі полібласти. У групі порівняння мікроскопічно визначали велику кількість МО, переважно паличкоподібних, та ознаки незавершеного фагоцитозу.

За даними мікроскопічного дослідження препаратів у пацієнтів обох груп з площею опіку 1 - 20\% та у пацієнтів групи спостереження 3 площею опіку 21 - 30\% цитограми віднесено до IV (запально-регенеративного) типу. В інших пацієнтів цитологічні маркери свідчили про розвиток запального процесу на фоні МК та повільну репарацію тканин (дегенеративно-запальний тип цитограми). 
За цитологічними показниками відбитків з поверхні ран на 14-ту добу після опіку встановлено позитивну динаміку перебігу ранового процесу у пацієнтів групи спостереження. Незалежно від площі опіку вміст нейтрофілів на рановій поверхні зменшувався до 50\%, частина цих клітин мала ознаки дистрофічних змін (вакуолізація цитоплазми, бліде забарвлення та ін.). Зростала кількість клітинних маркерів регенераторних процесів у рані. Сумарний вміст полібластів та фібробластів у препаратах становив 25 - 32\% (опіки площею до 30\%) та близько 12\% (тяжкохворі з площею ураження більше 30\%). Мікроскопічно в препаратах не виявляли МО, реєстрували лімфоцити та тучні клітини. За цитологічною картиною, що відповідала IV, V (регенераторному I, II фази) типам цитограм за Штенбергом, встановлено зменшення запалення, початок інтенсивного загоєння ран.

На відміну від групи спостереження, у групі порівняння вміст лейкоцитів та макрофагів практично не відрізнявся від показників, отриманих на 7-му добу дослідження. Вміст лейкоцитів становив від $(65,1 \pm 7,3) \%$ (площа опіків більше 50\%) до (79,2 $\pm 1,3) \%$ (площа опіків 31 - 50\%). Вміст маркерів регенерації (гістіоцитів) не перевищував 6,5 - 8\%, в незначній кількості серед інших клітин цитограми виявляли лімфоцити, тучні клітини. У пацієнтів з опіковою поверхнею більше 30\% продовжували виявляти еритроцити у великій кількості серед інших клітин та поодинокі тучні клітини, лімфоцити. МО були згруповані по декілька клітин, які слабо піддавались фагоцитозу і розташовувались переважно позаклітинно. Отже, у групі порівняння цитологічна картина ранового поверхневого шару свідчила про пролонгацію запальної фази та уповільнення репаративних процесів у рані. У цих пацієнтів, незалежно від площі ураження, цитограми віднесено до III (запально-регенераторного) типу за Штейнбергом.

Мікроскопічна оцінка активності репарації в рані та загоєння зони термічного ураження на 21-шу добу після опіку незалежно від площі ураження показала виражені відмінності цитологічних показників ранового ексудату у пацієнтів обох груп. Кількість та відносний вміст лейкоцитів у цитограмах пацієнтів з рановою площею до 30\% зменшувався до 35 - 40\% у групі спостереження порівняно з 69,5 - 80\% у групі порівняння. Більшість поліморфно-ядерних лейкоцитів у препаратах мали ознаки дегенерації. Повільнішу динаміку зменшення цитологічних маркерів запалення спостерігали при опіках площею більше 30\%. У пацієнтів групи спостереження в ранах відносний вміст лейкоцитів зменшувався до 51 61\%, у групі порівняння він становив 76 - 77\%.

У цитограмах ран пацієнтів групи спостереження визначено ознаки інтенсивної регенерації тканин: вміст полібластів та фібробластів у мазках-відбитках перевищував 16\% - при площі опіку більше 30\% та 32\% - при площі опіку до 30\%, що давало підстави цитограми в даній групі віднести до V (регенераторного II фази) типу за Штейнбергом. У групі порівняння показники цитограм відображали повільне загоєння ран незалежно від площі ураження, про що свідчили незначне зростання вмісту полібластів - від $(5,7 \pm 1,3) \%$ до $(8,9 \pm 3,5) \%$, вміст фібробластів менше 1\% (площа ураження до 20\% та більше 50\%) в порівнянні з даними, отриманими на 14-ту добу спостереження. Водночас у препаратах виявляли велику кількість МО, розташованих групами, переважно позаклітинно, фагоцитовані бактерії виявляли в незначній кількості в макрофагах. Таким чином, дані цитограм засвідчили уповільнення загоєння опікових ран у пацієнтів групи порівняння, перебіг ранового процесу залишався на рівні запально-дегенераторної фази (III тип).

Дослідженням впливу мікробного фактора на процес загоєння опікової рани за умов місцевого лікування різними антимікробними препаратами шляхом кількісного та якісного визначення домінуючих МО встановлено, що опікові рани незалежно від площі на початку спостереження були інфікованими. Ступінь МК, виражений в десяткових логарифмах, становив від log $(5,6 \pm 0,6)$ КУО/ мл - група порівняння до $\log (7,3 \pm 0,54)$ КУО/мл - група спостереження при площі опіку 31 - 50\%. При інших площах опіку МК коливався від $\log 6,3$ КУО/мл до $\log 6,7$ КУО/мл. Видовий склад ранової мікрофлори в цей період при площі опіку до 30\% переважно був представлений S.aureus, при площі опіку більше 30\% домінували штами A.baumannii здебільше в асоціаціях 3 коковою мікрофлорою.

Зменшення МК ранової поверхні у пацієнтів групи спостереження зафіксовано вже на 7-му добу після отримання опіку. Кількість МО при площі ураження до 30\% наближалась до кількісного критерію, за яким розмежовують інфіковані та колонізовані рани, і не перевищувала $\log 5$ КУО/мл. В обох групах при опіках площею більше 30\% показники колонізації зменшувались до $\log 5,9$ - 6,8 КУО/мл. Видовий спектр ранової мікрофлори був представлений переважно A.baumannii в монокультурі та асоціаціях.

В динаміці (14, 21-ша доба) встановлено зменшення МК збудниками ранової інфекції у пацієнтів групи спостереження. Серед колонізатів ідентифікували Corynebacterium spp., що свідчило про відновлення нормальної мікрофлори шкіри в процесі епітелізації ранової поверхні. У пацієнтів з площею опіків більше 30\% на 14-ту добу кількість МО в рані становила $\log 5,4-5,5$ КУО/мл, але вже на 21-шу добу іх кількість зменшувалась до $\log$ 4,3 - 2,4 КУО/мл, що свідчило про елімінацію МО з ран. У групі порівняння кількість МО переважно не змінювалась або зростала. На 21-шу добу дослідження у пацієнтів з площею опікової поверхні до 20\% кількість бактерій у ранах становила $\log (5,2 \pm 0,63)$ КУО/мл. При інших площах ураження у пацієнтів групи порівняння показники МК були вищі в 2 рази і більше. В ранах переважали штами A.baumannii в асоціаціях з іншими MO, P.aeruginosa, які домінували в ранах тяжкохворих 3 площею опіку більше 30\%.

\section{Обговорення}

Загоєння опікової рани у хворих з глибоким термічним ураженням тканин характеризується пролонгацією запальної фази, повільною регенерацією, а також ускладнюється за рахунок значної МК поверхні опікової рани та розвитком імуносупресивного стану при площі опіку понад 20\%. Ефективна тактика місцевого лікування опікової рани позитивно впливала на перебіг загоєння ран у цих пацієнтів. Оцінка ефективності лікувальних заходів потребує застосування об'єктивних методів ви- 
значення динаміки перебігу ранового процесу, адекватності місцевої та системної антимікробної терапії.

На наш погляд, цим вимогам відповідає метод цитологічного дослідження ранових відбитків як достатньо простий, доступний та ефективний спосіб оцінки динаміки загоєння рани. Місцеве застосування АМК з ДКМ прискорює процеси регенерації, про що свідчила поява в достатній кількості маркерів регенерації (полібластів або гістіоцитів, профібробластів) на 7-му добу спостереження, водночас кількість запальних клітин поступово зменшувалась. Цьому сприяло зменшення МК рани. У групі порівняння запальна фаза перебігу ранового процесу у більшості пацієнтів пролонгувалась до 21-шої доби, що підтверджено даними цитограм: перевищення вмісту лейкоцитів над вмістом клітин тканинного походження, які відповідають за регенерацію.

Стандартна місцева антимікробна терапія не мала очікуваного ефекту на елімінацію МО та не попереджала МК рани госпітальною мікрофлорою (Р. aeruginosa) у групі порівняння. У групі спостереження починаючи з 7-ї доби у хворих з опіками до 30\% поверхні тіла або з 14-ї доби у хворих з опіками більше 30\% поверхні тіла кількість збудників ранової інфекції зменшувалась, а видовий спектр поповнювався штамами коринебактерій, що є, на наш погляд, позитивною ознакою, оскільки свідчить про відновлення нормальної мікрофлори шкіри в зоні ураження. Появу Corynebacterium spp. можна розцінювати як своєрідний біологічний мікробний маркер початку епітелізації ранової поверхні. Процесу загоєння рани в групі спостереження сприяло повільне програмоване вивільнення ДКМ, що попереджало розмноження МО на рановій поверхні та ії подальшу колонізацію госпітальними штамами, а також зменшувало вплив детергенту на процес утворення грануляційної тканини.

\section{Висновки}

1. Цитологічно загоєння опікової рани у пацієнтів 3 глибокими термічними ураженнями тканин характеризується пролонгацією запальної фази перебігу ранового процесу, уповільненням регенерації, низькою ефективністю місцевих захисних реакцій, особливо при площі ураження більше 20\% поверхні тіла.
2. МК рани і недосконалість локальних механізмів захисту при тяжких опіках сприяють розвитку ранової інфекції та заселенню ранової поверхні умовнопатогенними МО, представленими переважно мікробними асоціаціями (S. aureus, A. baumannii, P. aeruginosaта ін.). Застосування АМК з ДКМ сприяє ефективній їх ерадикації починаючи з 7-мої доби - при опіковій поверхні до 30\% або з 14-тої доби - при опіковій поверхні більше $30 \%$.

3. Місцеве застосування АМК з програмованим виділенням ДКМ у порівнянні з традиційним застосуванням антисептиків прискорює початок репаративних процесів у рані за рахунок зменшення МК починаючи з 3-тьої доби та скорочення запального періоду в рані, про що свідчать збільшення вмісту фагоцитуючих клітин на початку лікування (3-тя доба - в 1,9 разу, р <0,01; 7-ма доба - в 2 рази, $\mathrm{p}<0,001)$, поява маркерів регенераторних процесів (полібластів, профібробластів на 7-му добу, $\mathrm{p}<$ 0,001), зменшення відносного вмісту лейкоцитів в цитограмах до 46,1 - 57,3\% (14-та доба) та 35,2 - 61,1\% (21ша доба) при значно кращому загоєнню ран.

\section{References}

1. Yin S, Jiang B, Huang G, Gong Y, You B, Yang Z, et al. Burn Serum Increases Staphylococcus aureus Biofilm Formation via Oxidative Stress. Front Microbiol. 2017;8:1191.doi: 10.3389/fmicb.2017.01191.

2. Church D, Elsayed S, Reid O, Winston B, Lindsay R. Burn Wound Infections. Clin Microbiol Rev. 2006;Apr; 19(2): 403-34. doi: 10.1128/ CMR.19.2.403-434.2006

3. Yali G, Jing C, Chunjiang L, Cheng Z, Xiaoqiang L, Yizhi P. Comparison of pathogens and antibiotic resistance of burn patients in the burn ICU or in the common burn ward. Burns. 2014;May;40(3):402-7. doi: 10.1016/j.burns.2013.07.010.

4. Nahaychuk VI, Nazarchuk OA, Paliy IH, Burkot VM, Honchar OO. Do kharakterystyky suchasnykh uskladnen' u khvorykh z opikamy. Ukrayins'kyy medychnyy chasopys. 2014;103(5):123-6. Available from: http://nbuv.gov.ua/UJRN/UMCh_2014_5_31

5. Rafla K, Tredget EE. Infection control in the burn unit. Burns. 2011 Feb;37(1):5-15. doi: 10.1016/j.burns.2009.06.198.

6. Nazarchuk OA, Nagaychuk VI Evaluation of the effectiveness of the use of decaetan, decamethoxin and its composition in patients with severe thermal. Annals of the Mechnikov Institute. 2015; 2: 184-90. Available from:http://nbuv.gov.ua/UJRN/ami_2015_2_35 